\title{
Trabecular bone score and dental implant
}

\author{
Scorul osului trabecular şi implantul dentar
}

\author{
Dan Perețianu', Adrian Sîrbu², Denis Păduraru³, \\ Dana Cristina Staicu', Aurelian Ranetti ${ }^{4}$ \\ ${ }^{1} \mathrm{SCM}$ „Povernei“, Bucureşti, România \\ ${ }^{2} \mathrm{CM}$ „Sana", Bucureşti, România \\ ${ }^{3}$ Institutul Naţional de Medicină Sportivă, Bucureşti, România \\ ${ }^{4}$ Departamentul de Endocrinologie, Spitalul Militar Central, Bucureşti, România
}

\begin{abstract}
Articolul aduce în acelaşi plan şi unifică vederi legate de două fenomene aparent diferite: implantul dentar (ID) şi osteoporoza.

1. ID şi osteoporoza. Reuşita ID depinde de calitatea osului. Una dintre contraindicaţiile relative ale ID este osteoporoza. Cu toate acestea, există studii care arată că ID poate reuşi şi la pacienţii cu osteoporoză. În cazuri de osteoporoză, reuşita depinde de lipsa tratamentelor antiosteoporotice anterioare de tip bifosfonaţi. 2. Diagnosticul osteoporozei. Se bazează pe valorile scorului T obţinut pentru densitatea minerală osoasă (DMO) în cadrul unor teste DEXA (dual X ray absorbtiometry); ele trebuie să fie < -2,5. Această valoare reprezintă deviaţia standard aplicată unei medii a adultului tînăr. Ce se întîmplă cu calitatea osului la pacienţii în vârstă posibil osteoporotici, dar cu DMO > -2,5? Problema diagnosticului poate fi rezolvată printr-o nouă tehnică DEXA: trabecular bone score.

3. Scorul osului trabecular (trabecular bone score, TBS) este aprecierea matematică a microarhitecturii vetebrelor, oase formate din os trabecular (osul lung este predominant os cortical). TBS se obţine prin analiza DEXA cu un soft specific. Valori < -2,5 înseamnă osteoporoză. Datele noastre arată că prin TBS creşte prevalenţa diagnosticului de osteoporoză cu circa $40 \%$, la pacienţii care au DMO în limitele considerate de osteopenie sau normale.

4. Relaţii între mandibulă/maxilar şi osul trabecular. Mandibula şi maxilarul sunt oase mixte. La suprafaţă se prezintă ca un os cortical, în profunzime au structură de os trabecular. Osul cortical (al mandibulei/maxilarului) este definit ca acea structură clară albă fără pattern trabecular. Osul trabecular este acea componentă a mandibulei care se regăseşte între două plăci corticale. Este adecvat a face un implant atunci când osul cortical este mai abundent. Se afirmă şi că implanturile efectuate în peste $60 \%$ de spaţii cu os trabecular (cancellous) sunt mai performante faţă de cele care sunt efectuate în sub $30 \%$ os trabecular. Fenomenul apare prin faptul că osul trabecular este mai activ metabolic şi conţine mai multe osteoblaste. TBS obţinut prin DEXA la nivelul coloanei poate fi surogat pentru aprecierea osului trabecular la nivelul mandibulei şi al maxilarului.

5. Medicamente care ameliorează scorul osului trabecular. Urmare a reanalizării diferenţei TBS-DMO prin tehnica TBS, s-a modificat percepţia asupra medicamentelor antiosteoporotice. Mai important este a ameliora TBS decît a creşte DMO. Astfel, ar fi de folosit preferenţial teriparatidul, apoi denosumabul, stronţiul, SERM şi apoi bisfosfonaţii. Mai mult, teriparatidul s-a dovedit singurul tratament valabil pentru necroza de mandibulă postbifosfonaţi.
\end{abstract}

Cuvinte cheie: maxilar, mandibulă, os trabecular, implant dentar, osteoporoză

ABSTRACT
The article brings in the same plan and unified views related to two different phenomena: dental implant (DI) and
osteoporosis.
1. DI and osteoporosis. Successful DI depends on bone quality. One of the relative contraindications of DI is
osteoporosis. However, there are studies showing that DI can be done in patients with osteoporosis. In cases of
osteoporosis, success depends on the lack of previous antiosteoporotic bisphosphonate treatments.
2, Diagnosis of osteoporosis. It is based on the T-score obtained for Bone Mineral Density (BMD) in DEXA (dual
X ray absortiometry) tests; they must be $<-2.5$. This value is the standard deviation applied to an average obtained
from adults. What happens to bone quality in patients with possibly osteoporosis but with BMD $>-2.5 ?$ The
problem of diagnosis can be solved by a new DEXA technique: trabecular bone score.


3. Trabecular bone score (TBS) is the mathematical estimation of vertebral microarhitectomy. The vertebra are formed by trabecular bone (the long bone is predominantly the cortical bone). TBS is obtained by DEXA analysis with specific software. A value $<-2.5$ means osteoporosis. Our data showed that through TBS analysis the prevalence of osteoporosis diagnosis increased by about $40 \%$ in patients who have BMD within the limits considered by osteopenia or normal.

4. Relationship between mandible/maxillary and trabecular bone. Mandible and the maxillary are mixed bones. At the surface it presents as a cortical bone, in depth, it presents with trabecular bone structure. The cortical bone (both of mandible \& maxillary) is defined as that white structure without a trabecular pattern. The trabecular bone is that part of the mandible that is found between two cortical plates. It is appropriate to make an implant when the cortical bone is more abundant. It is also stated that the implants performed in over $60 \%$ trabecular (cancellous) bone are more efficient than those performed in less than $30 \%$ of the trabecular bone. The phenomenon arises from the fact that the trabecular bone is more metabolically active and contains more osteoblasts. TBS obtained by DEXA for the vertebrae can be surrogate for the assessment of the trabecular bone in the mandible and maxillary.

5. Drugs that improve the trabecular bone score. Following the re-analysis of the TBS-BMD difference by the TBS technique, the perception of antiosteoporotic drugs has changed. More important is to improve TBS than increase BMD. Thus, teriparatide, then denosumab, strontium, SERM, and lastly bisphosphonates would be preferentially used. Furthermore, teriparatide was the only treatment available for post-bisphosphonates jaw necrosis.

Keywords: maxillary, mandible, trabecular bone, dental implant, osteoporosis

\section{IMPLANTUL DENTAR ŞI CALITATEA OSULUI}

Una dintre tehnicile cele mai prescrise pe plan mondial pentru tratarea căderii dinţilor este implantul dentar (1). Una dintre preocupările stomatologilor este dacă implantul asociat densităţii osoase scăzute se justifică şi dacă există diferențe de prognostic față de implanturile efectuate la pacienți cu oase intacte $(1,2)$. Meta-analizele pe această temă arată rezultate destul de neconcordante: fie loturile de analizat sunt neuniforme (2), fie există două categorii de rezultate/afirmații (1). Prima afirmaţie este că nu există diferențe între supraviețuirea unui implant la pacienții cu sau fără osteoporoză (3). A doua afirmație este că există diferențe între pierderea de os marginal al implantului la bolnavii cu osteoporoză față de cei fără osteoporoză (1). Dar pierderea de os marginal reprezintă un factor extrem de important pentru supraviețuirea implantului (4).

Preocuparea medicală există pentru că eliminarea/lipsa dinților apare la aceeaşi vârstă la care apare şi osteoporoza (5). La peste 65 de ani, australienii au lipsă 12 dinţi (3) şi osteoporoză în jur de $30 \%$. Prevalența este aceeaşi nu numai în Auastralia, dar şi în SUA şi Europa (6).

Rezultate conflictuale pot exista şi pentru că unii exprimă rezultatele în, ,supraviețuirea implantului“, iar alţii preferă „reuşita implantului“. Sub acest al doilea punct de vedere, la vârsta de peste 60 de ani, reuşita este de numai $78 \%$, față de $89 \%$ la 40-60 ani (7). Diferența pare a fi destul de mare. Cauzele par a fi că la această vârstă apar o mulține de comorbidităţi, dintre care unele reprezintă chiar contraindicații absolute pentru implant.

În afara contraindicațiilor absolute, osteoporoza este prima condiție analizată atunci când se discută contraindicațiile relative ale implantului (7). Menopauza este a doua! Ori, se ştie că osteoporoza este direct legată de menopauză (8).

Se afirmă că osteoporoza unui teritoriu nu înseamnă automat/neapărat că şi alte teritorii au osteoporoză. Explicația este că nu toate oasele au aceeaşi structură şi fiziologie. Se pare că regiunea anterioară a mandibulei este cea mai rezistentă la pierderea de os. Astfel că, la o pacientă/pacient cu osteoporoză, aprecierea masei osoase mandibulare trebuie efectuată direct, prin radiografie locală, sau $\mathrm{CT} / \mathrm{RMN}$, şi nu prin intermediul aparatelor DEXA, cele care afirmă diagnosticul de osteoporoză.

Prin perfecționarea cuantificării osteoporozei, s-a dezvoltat şi industria medicamentelor antiosteoporotice. În anii '90 ai secolului trecut, s-a început cu fluor, pentru ca apoi să se treacă la bifosfonați şi apoi la stronţiu. În ultimii ani, preparatele preferențiale sunt teriparatidul şi denosumabul.

O problemă importantă în stomatologie a fost generată de medicamentele anti-osteoporotice. Bifosfonaţii şi denosumabul, ca agenţi antiresorbtivi, au fost responsabili de apariţia a numerose cazuri de osteonecroză de mandibulă (9). Se admite că implanturile efectuate anterior tratamentelor cu bifosfonați sau cu denosumab nu produc necroză de mandibulă, în timp ce implanturile efectuate în cursul tratamentelor antiresorbtive produc necroza de mandibulă (9). Nu se ştie dacă implanturile sunt factorul favorizant pentru necroză sau faptul că pacientul, având osteoporoză şi fiind sub tratement, este la risc de osteonecroză postmedicamentoasă.

Un alt element important pare a fi concentraţia estrogenilor. Se admite că nivelul de estrogeni este extrem de corelativ cu densitatea minerală de la ni- 
velul maxilarului, mai puțin cu cea a manduibulei (3). În acest context, se ştie că femeile pierd os cu 2 ani înainte de menopauză, în momentul în care estradiolul scade sub un prag critic (pragul de pierdere al osului este mai mic, în sensul că nivelul de estradiol trebuie să fie mai mare decît cel al uterului; uterul este sensibil la nivele mici de estradiol!) (8).

\section{DIAGNOSTICUL OSTEOPOROZEI}

Standardul „de aur“ în diagnosticul osteoporozei este considerat a fi densitatea minerală osoasă (DMO), obținută în cadrul analizei numită dual energy X-ray absorbtiometry (DEXA) (10). DMO este obținută prin diferențierea, adică absobția, dintre puterea a două unde de raze $X$, amândouă de amplitudine scăzută. Datele post-absorbție la nivelul corpului sunt colectate pe o suprafață sensibilă specifică. Diferențierea dintre unda/raza X cea mai puternică față de unda/raza X cea mai slabă produce un raport, numit „R“. Acest raport „R“ este specific pentru fiecare țesut, astfel că prin DEXA se pot analiza nu numai densitatea osului, ci şi structura muşchilor şi a țesuturilor grase. În baza raportului generat de diferența dintre cele două unde, softuri care folosesc algoritmi complicați au ajuns să estimeze în grame/centrimetru pătrat $\left(\mathrm{g} / \mathrm{cm}^{2}\right)$ densi- tatea osului, numită ,densitate minerală osoasă“ (Fig. 1).

Convențional, se admite că diagnosticul de osteoporoză este nivelul mediei persoanelor adulte minus 2,5 deviații standard $(-2,5)$, numit „scor $\mathrm{T}^{\text {“. }}$. Atunci când scorul $\mathrm{T}$ este între -1 şi $-2,5$, situaţia clinică se numeşte „osteopenie“.

În ciuda acestei aserțiuni legate de o mărime certă şi un test de o valoare incontestabilă, observația clinică era că, în multe cazuri, persoane cu osteoporoză şi chiar cu fracturi osteoporotice au valori DMO mai mari de $-2,5$ la scorul $\mathrm{T}$ (valori mai mari înseamnă valori matematic mai mari, adică spre 0 sau spre pozitiv).

În urmă cu cîțiva ani, am pus problema mediei medicale româneşti (11) dacă nu cumva se pierd diagnosticului prea mulţi pacienți/paciente. Fenomenul patologic este că osul - vertebra - s-a tasat, astfel că, pe o suprafață/arie nemodificată, s-a modificat volumul. Ori, la aceeaşi cantitate de substanță, un volum mai mic generează o densitate mai mare.

\section{SCORUL OSULUI TRABECULAR}

Din aceste motive, cercetătorii în domeniu au încercat alte tehnici de cuantificare a leziunilor osoase care să permită diagnosticul de osteoporoză.
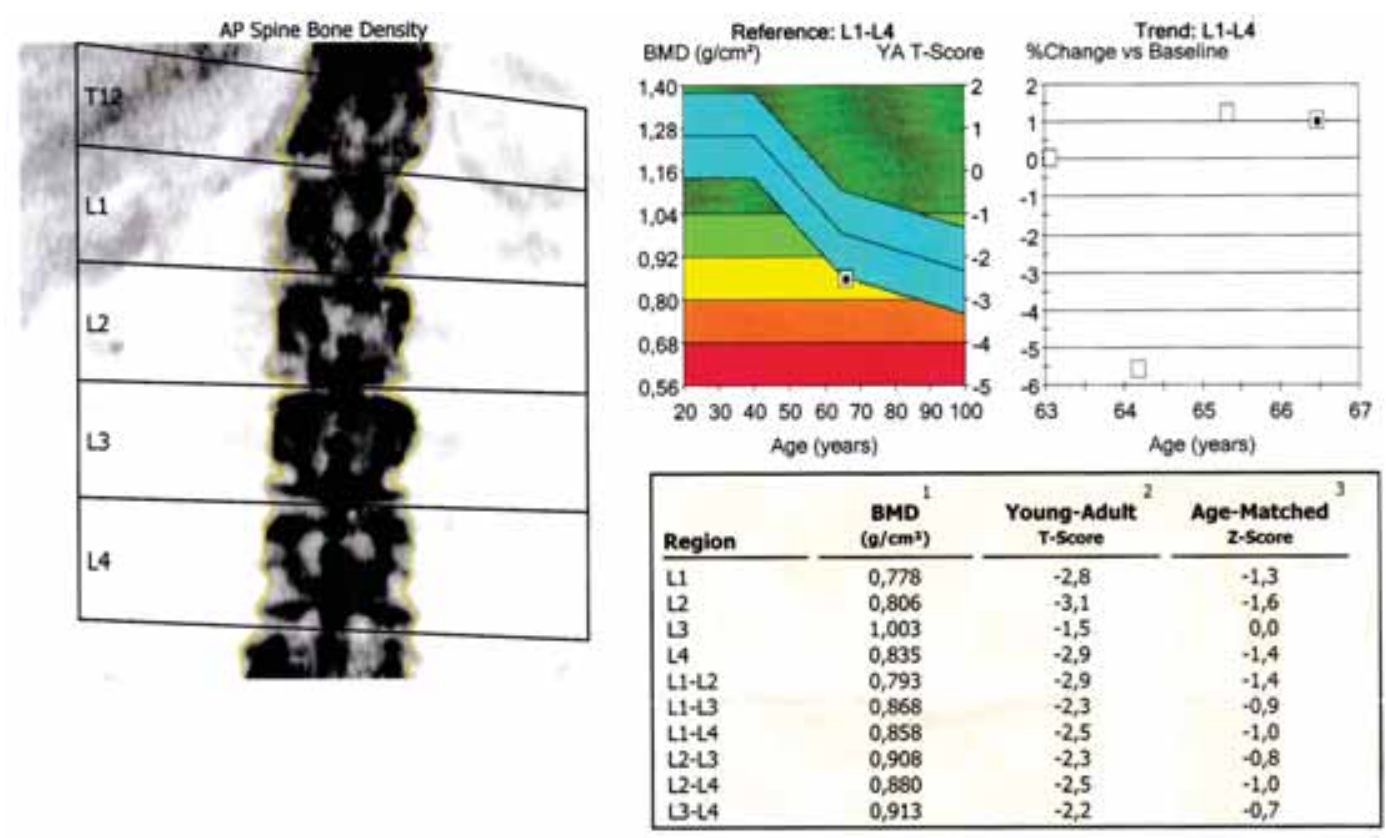

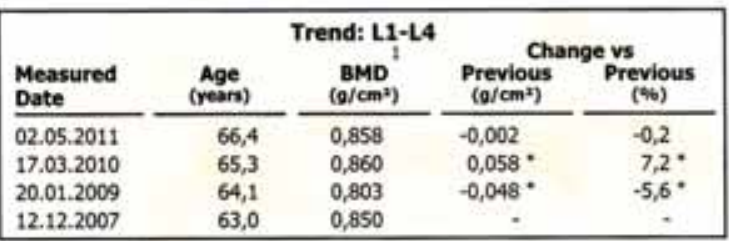

FIGURA 1. Analiză a densității minerale osoase într-o DEXA „clasică“ (colecția dr. A. Sîrbu) 
Astfel, a apărut TBS - trabecular bone score, i.e., scorul osului trabecular. Osul „trabecular“ este caracteristic vertebrelor, în timp ce osul lung este un os ,cortical“.

TBS vertebral este o analiză cantitativă tridimensionată ce poate fi extrasă matematic la nivelul coloanei vertebrale lombare printr-o proiectie bidimensională a unei investigații DEXA, pe un suport sensibil DEXA. Elementele de sensibilitate ale aparatului trebuie să fie însă extrem de mari, pentru a permite ca softuri complexe să analizeze „resturi-

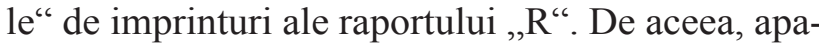
ratele trebuie să fie noi. Observațiile au fost că astfel de imprinturi există şi că ele pot fi analizate, algoritmate şi introduse în softuri specifice.

Analiza matematică pentru a ,extrage“ date folositoare clinice a fost extrem de complexă şi a presupus (12): conversie Fournier, analiza fractaliilor şi analiză run-length matrix (matrice run-lungime). Aceste date matematice, în relație cu pixelii şi densitatea radiației, generează un examen computerizat tridimensional. Analizele matematice au fost validate de experimente: în cursul DEXA, s-au efectuat biopsii osoase de la cadavre sau din operații de vertebre care au permis ameliorarea măsurătorilor.

Important este că această tehnică necesită un soft special instalat pe maşini (aparate) DEXA. Evident, softul trebuie cumpărat de la firme ce au trecut deja prin ciurul experimentărilor şi ameliorărilor. Partea bună a acestui soft este că se poate monta pe orice maşină DEXA mai veche, dar com- patibilă (i.e. destul de nouă!), şi că toate înregistrările vechi păstrate în memoria maşinii efectuate pot fi reanalizate (13).

TBS este legat de microarhitectura osoasă şi oferă informații despre arhitectura intimă a scheletului. TBS este bazat pe variograme experimentale generate de imagini proiectate de DEXA. TBS are potențialul de a discerne diferențe între scanări DEXA care arată măsurători DMO similare (Fig. 2). $\mathrm{O}$ valoare ridicată TBS se corelează mai bine cu microstructura scheletică față de DMO.

TBS se efectuează la nivelul coloanei vertebrale lombare. Tehnica a fost evaluată în studii transversale şi longitudinale. Următoarele concluzii se bazează pe publicaţiile analizate $(12,14,15,16,17)$.

1. TBS oferă valori mai mici la femeile în postmenopauză şi la bărbații cu fracturi de fragilitate anterioare;

2. TBS este complementară datelor disponibile prin măsurători DEXA ale coloanei vertebrale lombare;

3. Rezultatele TBS sunt mai mici la femeile care au suferit o fractură de fragilitate, dar la care $\mathrm{DMO} /$ BMD nu indică osteoporoză sau indică doar osteopenie;

4. TBS prezice mai corect riscul de fractură, față de măsurătorile $\mathrm{DMO} / \mathrm{BMD}$ la nivelul coloanei vertebrale lombare la femeile în postmenopauză;

5. Terapiile eficace pentru osteoporoză s-au dovedit diferite de cele bazate pe $\mathrm{DMO} / \mathrm{BMD}$, în măsura în care acestea influențează mai mult TBS;
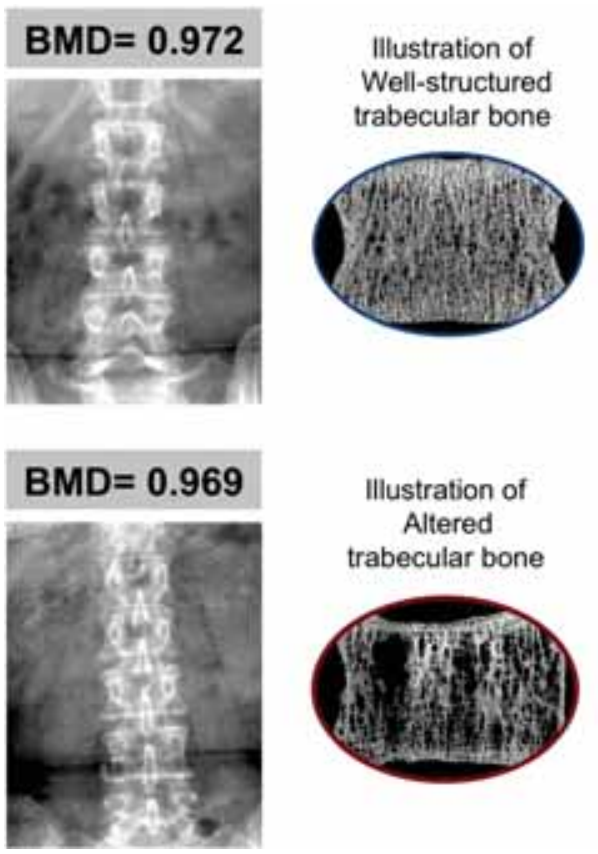

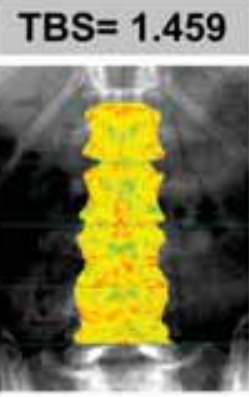

Experimental variogram

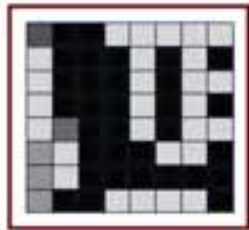

TBS $=1.243$

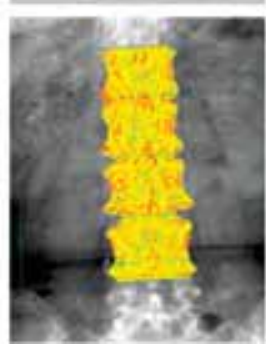

FIGURA 2. Diferență de TBS la un nivel DMO asemănător (14) 
6. TBS este asociată cu riscul de fractură la persoanele cu condiții legate de masa osoasă redusă, dar influențate doar de calitatea proastă a osului.

Ulterior, prin acumularea de numeroase date epidemiologice statistice, şi pentru TBS s-a construit un scor T, care este media TBS la vârsta adultă minus 2,5 $(-2,5)$ deviații standard.

Datele noatre arată că $47,9 \%$ dintre pacienți se pierd diagnosticului de osteoporoză prin DMO (Fig. 3). Cauza acestei diferențe constă probabil în vârsta lotului nostru (18). Lotul nostru de analiză are o medie de 66,28 ani, considerată ca avansată. La această vârstă, probabil, se produc multe tasări vertebrale care induc în eroare medicii care NU pun diagnosticul de osteoporoză! (pentru detalii, vezi referința 18).

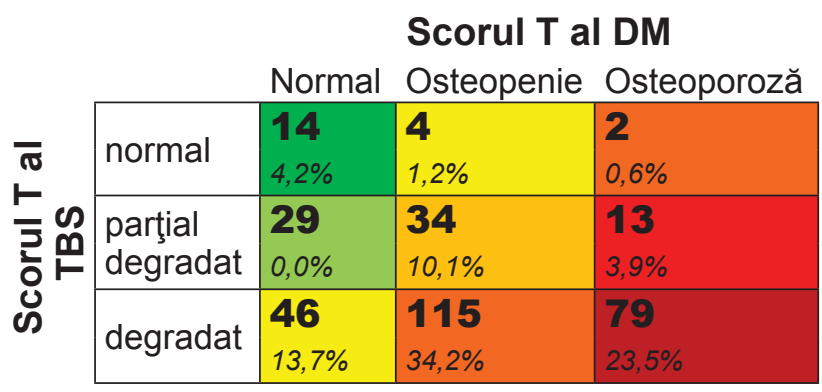

FIGURA 3. Analiză de repartiție a valorilor scorurilor TBD şi DMO la pacienții noştri (18)
Din analiza figurii 3 se observă că aceşti 47,9\% dintre pacienți provin din 46 de pacienți cu DMO > -1 şi din 115 pacienţi cu DMO între -1 şi $-2,5$. Pe de altă parte, dacă am fi folosit la diagnosticul de osteoporoză numai TBS, nu şi DMO, s-ar fi pierdut din diagnosticul de osteoporoză, diagnosticabil prin DMO, 2 pacienți, adică $0,6 \%$.

Aceste date arată importanţa TBS în explorarea osteoporozei la un lot de pacienți foarte în vârstă!

S-a arătat mai de mult că valori asemănătoare ale densității minerale osoase pot induce în eroare diagnosticul dacă nu se face şi analiza TBS. Barbara Silva (14) arată că, prin TBS, diagnosticul osteoporozei creşte cu $24 \%$, cifră destul de departe de 47\%! (Fig. 4).

Astfel, la pacienții mai în vârstă, DEXA simplă, numai cu analiză a DMO, sugerează deseori valori normale, când pacientul/pacienta are de fapt osteoporoză.

\section{RELAŢII ÎNTRE MANDIBULĂ/MAXILAR ŞI OSUL TRABECULAR}

Mandibula şi maxilarul sunt oase mixte. La suprafață se prezintă ca un os cortical, în profunzime au structură de os trabecular. Osul cortical (al mandibulei/maxilarului) este definit ca acea structură

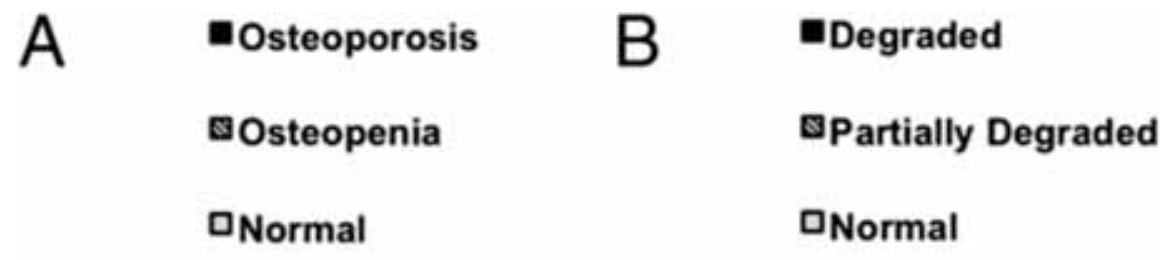

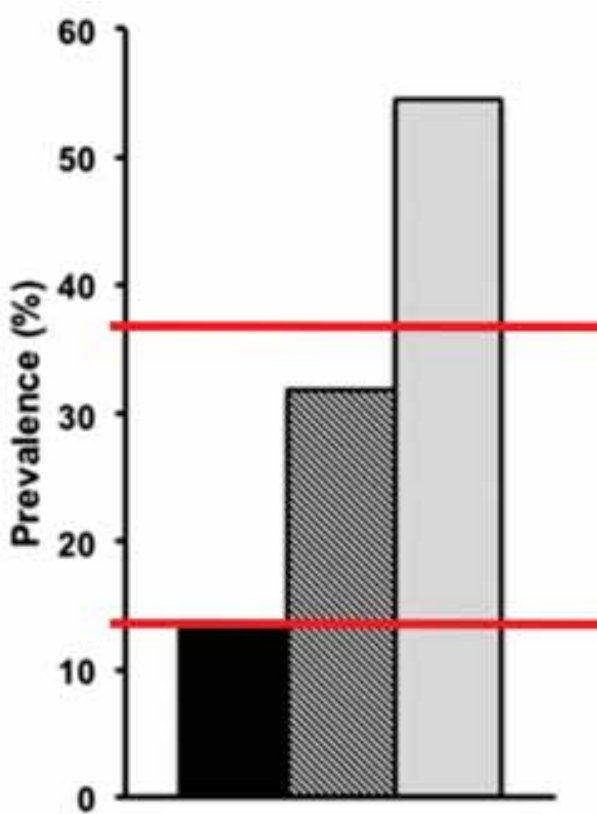

L1-L4 aBMD

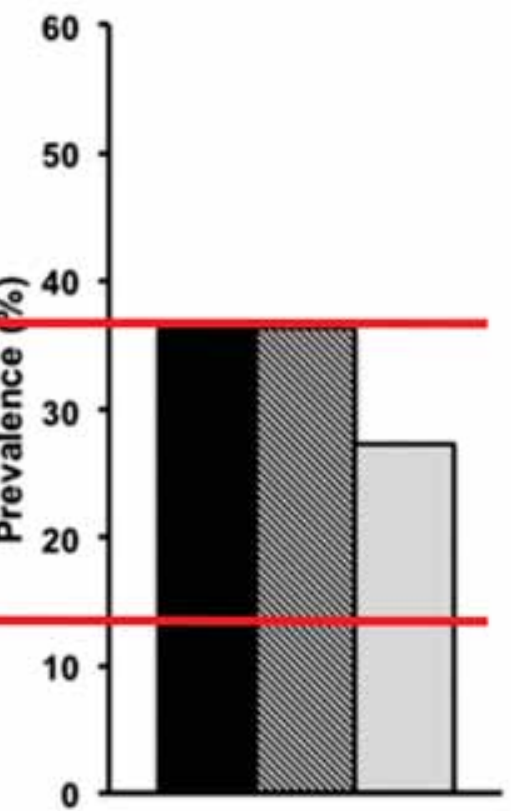

L1-L4 TBS
FIGURA 4. Diferențe între procentajele de osteoporoză generate de analiza BMD (13\%) vs. TBS (37\%) (14) 
clară albă fără pattern trabecular. Osul trabecular este acea componentă a mandibulei care se regăseşte între două plăci corticale (19).

Dinții sunt susținuți de mandibulă şi de maxilar prin două tipuri de oase: osul alveolar şi osul trabecular. Funcția masticatorie pare a fi direct corelată cu morfologia osului trabecular (20).

Modul în care se realizează implantul în funcţie de tipul de os poate conduce la succesul operațiunii sau nu. Se afirmă că este adecvat a face un implant atunci când osul cortical este mai abundent - tipurile 1-3 şi că nu este indicat a face implant dacă există tipul 4 de os (Fig. 5) (7).

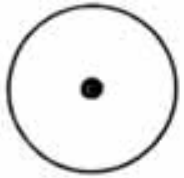

1

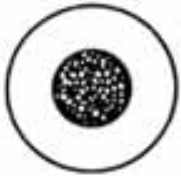

2

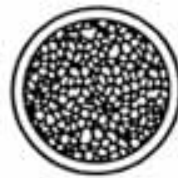

3

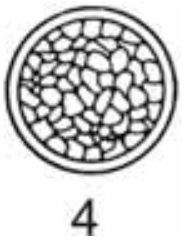

4
FIGURA 5. Clasificarea „clasică“ a lui Lekholm and Zarb (vezi în Chugh, 2013, toate tipurile de clasificări) (21) pentru tipuri de structuri osoase mandibulare. Porțiunea centrală a fiecărei forme de os mandibular conține os trabecular.

Alții (19) susțin că implanturile efectuate în peste $60 \%$ de spații cu os trabecular (cancellous) sunt mai performante față de cele care sunt efectuate în sub 30\% os trabecular, mai ales la nivelul maxilarului (21). Pierderea de os marginal în primul caz este mult mai mică. Evident, alegerea poate fi efectuată numai după analize CT ale mandibulei/maxilarului. Fenomenul apare prin faptul că osul trabecular este mai activ metabolic și conține mai multe osteoblaste.

În acest context, este important a analiza şi structura acestui tip de os. Tipul 4 din figura 5 prezintă un os trabecular extrem de rarefiat, care nu este adecvat unui implant. Acest tip de os trabecular este caracteristic persoanelor în vârstă. Acest tip de os trabecular trebuie evitat, iar analiza TBS obținut prin DEXA la nivelul coloanei poate fi surogat pentru aprecierea osului trabecular la nivelul mandibulei şi al maxilarului, la fel cum DMO de la nivelul şoldului este surogat pentru DMO de la nivelul mandibulei.

\section{MEDICAMENTE CARE AMELIOREAZĂ SCORUL OSULUI TRABECULAR}

Urmare a reanalizării diferenței TBS-DMO prin tehnica TBS, s-a pus problema dacă această tehnică îndrumă spre alte abordări în terapia osteoporozei. De exemplu, atunci când denistatea minerală osoasă creşte prin bifosfonați, TBS nu creşte în aceeaşi

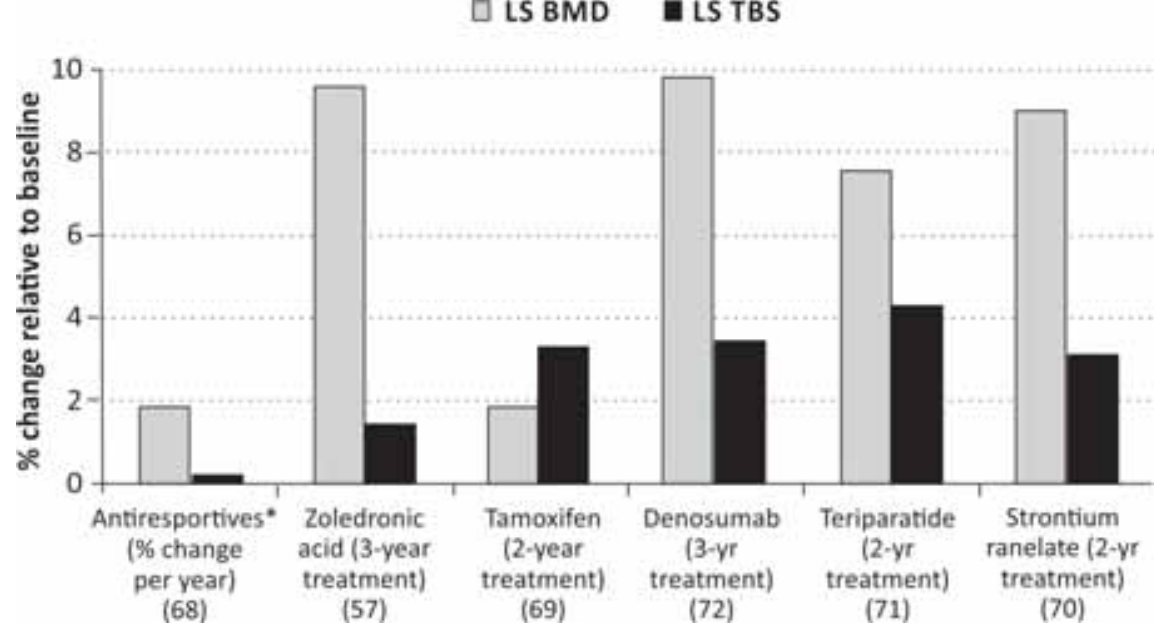

FIGURA 6. Modificări în DMO/BMD vs TBS după folosirea unor medicamente pentru osteoporoză (12)

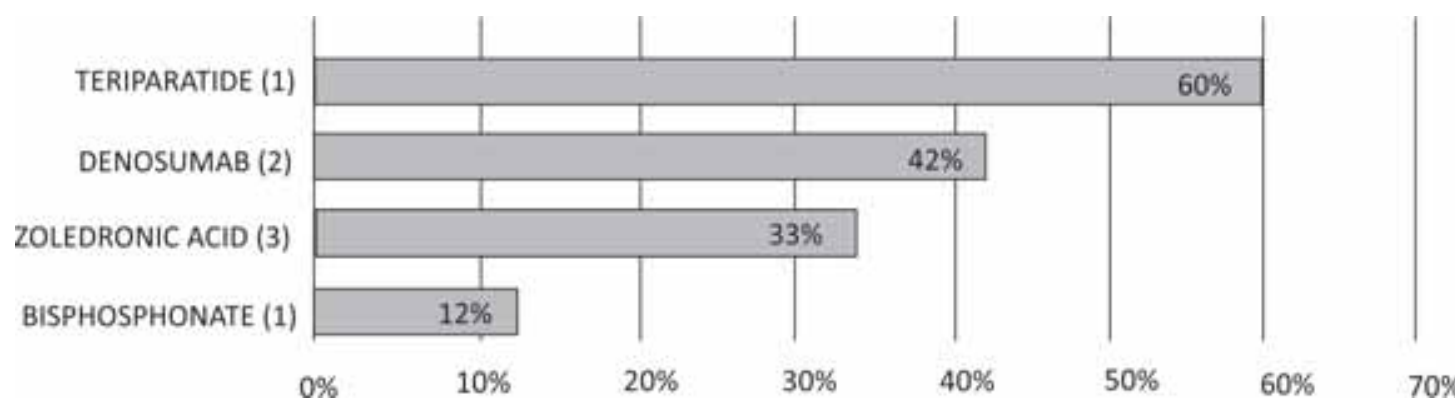

FIGURA 7. Efecte (ne)-comparabile pe TBS după diferite tratamente antiosteoporotice (22) 


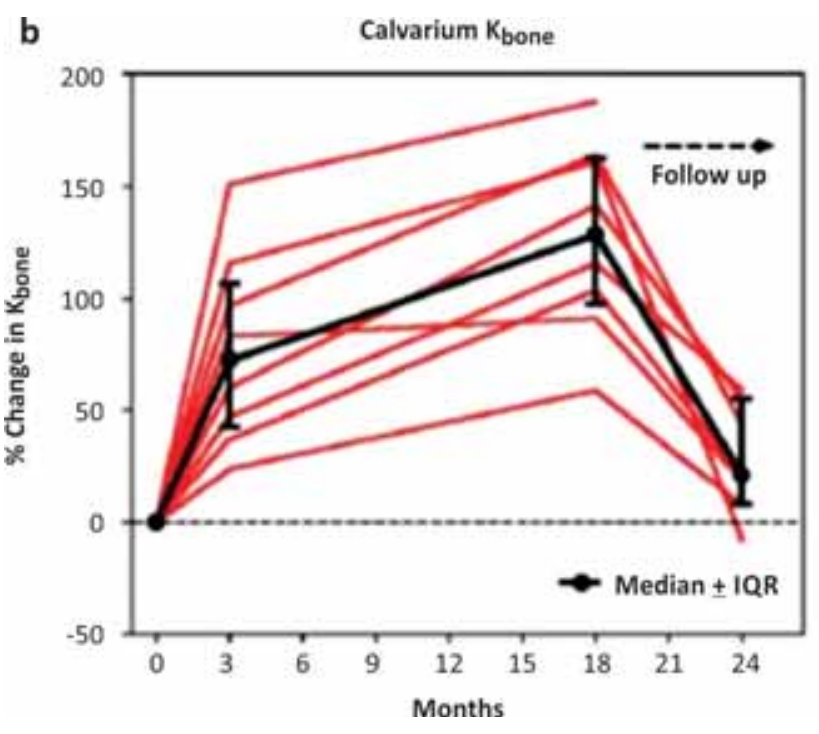

FIGURA 8. Creşterea captării ${ }^{99} T c$ metilen difosfonat administrare de PTH 1-34 pentru 18 luni (23)

măsură. De aceea, tehnica TBS a condus la modificarea terapiei în osteoporoză. Datele dintre măsurătorile $\mathrm{DMO} / \mathrm{BMD}$ şi cele ale TBS sunt concluden(MDP) la nivelul craniului, incluzând şi mandibula, după

te: cele mai eficace tratamente nu sunt cele care cresc DMO/BMD, ci cele care cresc scorul TBS (Fig. 6 şi Fig. 7).

Cele mai importante efecte (eficacitatea măsoară un rezultat) se observă după parathormon de tip teriparatid ${ }^{\mathrm{DCI}}\left(\right.$ Forsteo $\left.^{\mathrm{R}}\right)$. Administrarea de tamoxifen/raloxifen, denosumab şi ranelat de stronţiu generează rezultate/efecte ceva mai mici.

Administrarea de teriparatid (PTH 1-34) conduce la creşterea captării tehnețiului 99 , radiotrasor care evidenţiază formarea osului (Fig. 8) (23).

TBS a consacrat teriparatidul ca tratament esențial în osteoporoză. În plus, teriparatidul s-a dovedit singurul tratament eficace şi în necroza de mandibulă apărută pe fond de implant dentar la pacienții anterior tratați cu bifosfonați! $(24,25)$.

Colegii stomatologi trebuie să ştie valoarea TBS, pentru că, dacă aceasta este mică, i.e. pacienta are osteoporoză, trebuie propusă terapia cu PTH 1-34. Aceasta din urmă este extrem de benefică pentru mandibulă, astfel că stomatologii pot propune implantul dentar chiar şi la vârste foarte înaintate. Mai ales după terapia cu teriparatid!

\section{Conflict of interest: none declared} Financial support: none declared

\section{BIBLIOGRAFIE}

1. de Medeiros F.C.F.L., Kudo G.A.H., Leme B.G., Saraiva P.P., Verri F.R., Honório H.M., Pellizzer E.P., Santiago Junior J.F. Dental implants in patients with osteoporosis: A systematic review with meta-analysis. Int J Oral Maxillofac Surg., 2018, Apr; 47, 4: 480-491.

2. Radi I.A., Ibrahim W., Iskandar S.M.S., AbdelNabi N. Prognosis of dental implants in patients with low bone density: A systematic review and meta-analysis. J Prosthet Dent., 2018, Jul 10; pii: S00223913(18)30094-5.

3. Dreyer H., Grischke J., Tiede C., Eberhard J., Schweitzer A., Toikkanen S.E., Glöckner S., Krause G., Stiesch M. Epidemiology and risk factors of peri-implantitis: A systematic review. J Periodontal Res., 2018, Jun 7; doi: 10.1111/jre.12562.

4. Bressan E., Grusovin M.G., D’Avenia F., Neumann K., Sbricoli L., Luongo G., Esposito M. The influence of repeated abutment changes on peri-implant tissue stability: 3-year post-loading results from a multicentre randomised controlled trial. Eur J Oral Implantol. 2017, 10, 4: $373-390$.

5. Chen C.H., Wang L., Serdar Tulu U., Arioka M., Moghim M.M., Salmon B., Chen C.T., Hoffmann W., Gilgenbach J., Brunski J.B., Helms J.A. An osteopenic/osteoporotic phenotype delays alveolar bone repair. Bone, 2018, Jul; 112: 212-219.

6. International Osteoporosis Foundation. www.iofbonehealth.org/ epidemiology; 2018.

7. Dudley J. Implants for the ageing population. Aust Dent J., 2015, Mar; 60, Suppl 1: 28-43.

8. Pereţianu D. Trebuie tratate femeile la menopauză cu estrogeni? Răspuns: DA. Partea I-a. Medica Academica (Buc.), 2017-2018, 9-10: Decembrie-lanuarie; 83-1: 18-23. Partea II-a. Medica Academica (Buc.), 2018, 11: Februarie; 84-2: 26-30. Partea III-a. Medica Academica (Buc.), 2018, 11: Martie; 85-3: 34-37. Partea III-a. Medica Academica (Buc.), 2018, 11: Aprilie; 86-4: 30-33.

9. Japanese Allied Committee on Osteonecrosis of the Jaw, Yoneda T., Hagino H., Sugimoto T., Ohta H., Takahashi S., Soen S., Taguchi A.,
Nagata T., Urade M., Shibahara T., Toyosawa S. Antiresorptive agent-related osteonecrosis of the jaw: Position Paper 2017 of the Japanese Allied Committee on Osteonecrosis of the Jaw. J Bone Miner Metab., 2017, Jan; 35, 1: 6-19.

10. Guerri S., Mercatelli D., Aparisi Gómez M.P., Napoli A., Battista G., Guglielmi G., Bazzocchi A. Quantitative imaging techniques for the assessment of osteoporosis and sarcopenia. Quant Imaging Med Surg., 2018, Feb; 8, 1: 60-85.

11. Pereţianu D., Poiană C. Controverse legate de DEXA. Viaţa Medicală (Buc.), 2016, 28, 7 (1361): 3.

12. Silva B.C., Leslie W.D., Resch H. et al. Trabecular Bone Score: A noninvasive analytical method based upon the DXA image. Journal of Bone and Mineral Research, 2014, March; 29,3: 518-530.

13. Leslie W.D., Aubry-Rozier B., Lamy O., Hans D. Manitoba Bone Density Program. TBS (trabecular bone score) and diabetes-related fracture risk. J Clin Endocrinol Metab., 2013, Feb; 98, 2: 602-609.

14. Silva B.C., Boutroy S., Zhang C., McMahon D.J., Zhou B., Wang J., Udesky J., Cremers S., Sarquis M., Guo X.D., Hans D., Bilezikian J.P. Trabecular bone score (TBS) - a novel method to evaluate bone microarchitectural texture in patients with primary hyperparathyroidism. J Clin Endocrinol Metab., 2013, May; 98, 5: 1963-1970.

15. Harvey N.C., Glüer C.C., Binkley N. et al. Trabecular bone score (TBS) as a new complementary approach for osteoporosis evaluation in clinical practice: A consensus report of a European Society for Clinical and Economic Aspects of Osteoporosis and Osteoarthritis (ESCEO) Working Group. Bone, 2015, September; 78: 216-224.

16. Luckman M., Hans D., Cortez N., Nishiyama K.K. et al. Spine trabecular bone score as an indicator of bone microarchitecture at the peripheral skeleton in kidney transplant recipients. Clin J Am Soc Nephrol., 2017, Apr 3; 12, 4: 644-652.

17. Tamaki J., Iki M., Sato Y., Winzenrieth R., Kajita E., Kagamimori S. JPOS Study Group. Does Trabecular Bone Score (TBS) improve the 
predictive ability of FRAX for major osteoporotic fractures according to the japanese population-based osteoporosis (JPOS) cohort study? J Bone Miner Metab., 2018, Feb 21; doi: 10.1007/s00774-018-0910-7. (Epub ahead of print).

18. Pereţianu D., Sîrbu A., Păduraru D., Staicu D.C., Ranetti A. O nouă tehnică pentru diagnosticul osteoporozei: Trabecular bone score. Medica Academica, 2018, 11, submitted.

19. Simons W.F., De Smit M., Duyck J., Coucke W., Quirynen M. The proportion of cancellous bone as predictive factor for early marginal bone loss around implants in the posterior part of the mandible. Clin Oral Implants Res., 2015, Sep; 26, 9: 1051-1059.

20. Watson P.J., Fitton L.C., Meloro C., Fagan M.J., Gröning F. Mechanical adaptation of trabecular bone morphology in the mammalian mandible. Sci Rep., 2018, May 8; 8, 1: 7277.

21. Chugh T., Jain A.K., Jaiswal R.K., Mehrotra P., Mehrotra R. Bone density and its importance in orthodontics. J Oral Biol Craniofac Res., 2013, May-Aug; 3, 2: 92-97.
22. Hans D. New insites on trabecular bone score. $1^{\text {st }}$ Regional AACE International Chapters' Meeeting, Bucharest, 2.10.2015.

23. Moore A.E., Blake G.M., Taylor K.A., Ruff V.A., Rana A.E., Wan X., Fogelman I. Changes observed in radionuclide bone scans during and after teriparatide treatment for osteoporosis. Eur J Nucl Med Mol Imaging, 2012, Feb; 39, 2: 326-336.

24. Khan A.A., Morrison A., Hanley D.A. et al - for International Task Force on Osteonecrosis of the Jaw. Diagnosis and management of osteonecrosis of the jaw: a systematic review and international consensus. J Bone Miner Res., 2015, Jan; 30, 1: 3-23.

25. Zushi Y., Takaoka K., Tamaoka J., Ueta M., Noguchi K., Kishimoto H. Treatment with teriparatide for advanced bisphosphonate-related osteonecrosis of the jaw around dental implants: a case report. Int J Implant Dent. 2017 Dec; 3(1):11. doi: 10.1186/s40729-017-0074-6. Epub 2017 Mar 30. 